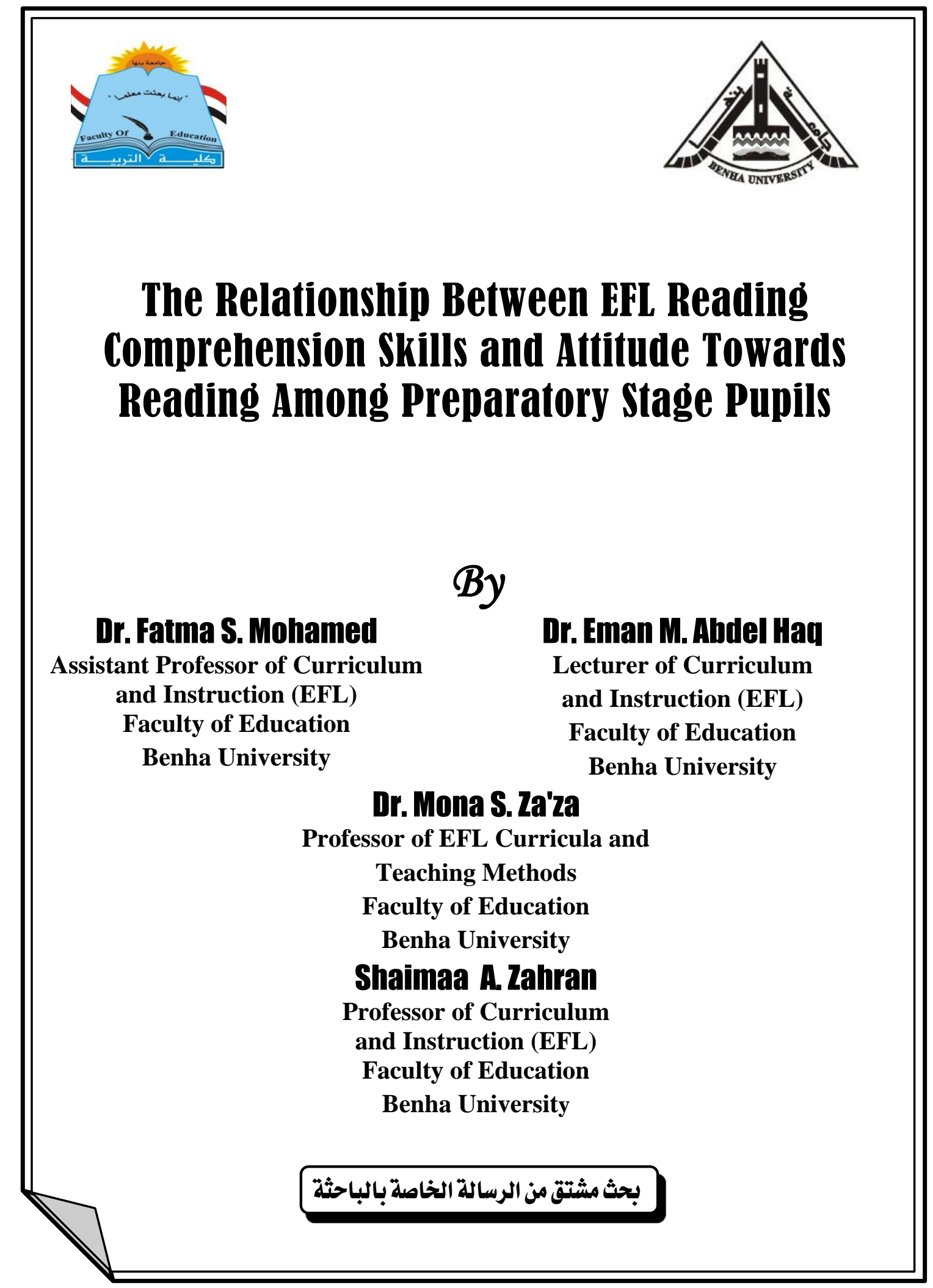




\section{The Relationship Between EFL Reading Comprehension Skills and Attitude Towards Reading Among Preparatory Stage Pupils}

\begin{tabular}{cc}
\multicolumn{1}{c}{ By } & \\
Dr. Fatma S. Mohamed & Dr. Eman M. Ahdel Hau \\
Assistant Professor of Curriculum & Lecturer of Curriculum \\
and Instruction (EFL) & and Instruction (EFL) \\
Faculty of Education & Faculty of Education \\
Benha University & Benha University \\
Dr. Mona S. Za'za & Shaimaa A. Zahran \\
Professor of EFL Curricula and & Professor of Curriculum \\
Teaching Methods & and Instruction (EFL) \\
Faculty of Education & Faculty of Education \\
Benha University & Benha University
\end{tabular}

Alsstract

The aim of this research was to investigate the relationship between EFL reading comprehension skills and attitude towards reading among preparatory stage pupils. The participants were forty pupils in second year from Al-Shaheed Ahmed Hamid Abdel Dayem - a preparatory school at Al-Menofia Governorate. The participants of the study were divided into three groups, two experimental groups (group one was consisted of ten pupils and the second group was also consisted of ten pupils and the control group was consisted of twenty pupils. The instruments of the research were a pre-comprehension reading test, a post-comprehension reading test, a proficiency rating scale for correcting the tests and a scale for assessing the pupils attitude towards reading. Results of the research revealed that there is a strong correlation relationship between the EFL reading comprehension skills and attitude towards reading.

Key words: EFL reading comprehension skills, attitude towards reading 


\section{Introduction}

There are different reasons for studying a foreign language. Many language students in the world do it because it is on the curriculum. Some people study English or any other foreign language because they think it helps them in their career. People can get a better job with a foreign language than having the mother tongue only. English has become the international language of communication.

Harmer ( 2007) asserted that teachers tend to talk about the way we use language in terms of the four skills- listening, speaking, reading and writing. These are often divided into two types. Receptive skills is a term used for reading and listening, skills were meaning is extracted from the discourse. Productive skills is a term for speaking and writing, skills were students actually have to produce language themselves

Among all language skills reading is one of the four main skills that students of foreign languages need to master in order to successfully learn the language. Also, it is one of the main activities of everyday life as everyone is engaged in reading in a way or another. Therefore, reading is one of the most significant ways of acquiring knowledge. Successful reading, not only improves the quality and quantity of knowledge, but also the use of time whether it is applied in different study contexts or learning of various academic subjects (Rraku, 2013).

The purpose of teaching reading is to develop the readers' attitudes, abilities and skills needed for obtaining information, fostering, reacting to ideas, developing interests and finally deriving pleasure by reading through comprehension. Reading comprehension is 
one of the most important objectives of the reading process. It is the first point to be made about the reading process. Comprehension depends on knowledge and relating what we do not know or new information to what we already know Mohamed, Abdel-Haq and Helwa (2010). In the same context, Aly (2005) and Abdel-Haq (2009) indicated that the goal of all reading instruction is to help students become experts readers who can use strategies effectively to construct meaning, achieve independence and use literacy for lifelong learning and enjoyment. Consequently, reading instruction should and can assist EFL/ ESL students to make the transition from" learning to read" to "reading to learn".

Hashey and Conners (2003) asserts that comprehension is the ultimate goal of reading. Reading comprehension is defined as a process of extracting and constructing meaning through interaction and involvement with written language. The words extracting and constructing are used to emphasize both the importance and the insufficiency of the text as a determinant of reading comprehension. It entails three elements the reader who is doing the comprehending, the text that is to be comprehended, and the activity in which comprehension is apart.

Rahman (2007:) stated that "reading is not just an act of going through the text, but it involves certain attitudes and reactions towards the text while reading the text. The author added that "reading is not a passive skill. It requires frequent practice and exercise".

Joseph, (2004) asserts that children with positive reading attitudes tend to be willing to read, enjoy reading, become proficient, 
and become lifelong readers. On the other hand, children with poor attitudes toward reading may only read when they have to read, tend to avoid reading, and may even refuse to read altogether. A child's attitude toward reading may have a profound impact upon his or her overall academic progress.

\section{Background of the problem:}

Kewaza \& Welch (2013) and Deane \& Song (2014) indicate that reading is important in the daily life of most people. It is functional when people read road signs, maps, recipes, labels, fill forms, or apply for jobs. It is fundamental to school achievement, and hence, learning to read at the appropriate time is crucial to one's academic success .All school subjects require reading various written materials like graphs, charts, maps and tables.

Therefore, Nation, Cocksey, Taylok and Bishop (2010), Macaruso and Shankweiler (2010), Roch, Florit and Levorato (2011), Grant, Gottardo and Geva( 2012) and Gentaz, Charolles and Theurel (2015) assert that reading for meaning requires both general language and specific reading abilities. According to the simple view of reading, learners need to become proficient at two sets of skills to be skilled readers. They need to learn how to get the meaning of the printed words, and they also need to learn how to comprehend the message that words convey.

Accordingly, there are two different categories that define reading. First, there are those who view reading as only decoding process of the written words. The second view considers reading as a process for getting the meaning. So it is considered as a comprehension process. 
Comprehension is the ultimate goal of reading and comprehension failures can lead to school failures. The ultimate goal of reading is to create sophisticated readers who can experience what it is like being inside a book, with their thoughts and emotions involved in the events and feelings of the story (Sorba ,1995).

Fountas and Pinnell (2001) asserted that, reading for meaningcomprehending- is the goal of every reading episode. Teachers want students not only to understand what they read, but also to enjoy texts, interpret them, and apply their learning from reading to other areas.

Reading comprehension involves four processes. These are: seeing the printed words, associating meanings with the words, being psychologically part of the text and finally, integrating the text with one's experience. These processes are following though unconsciously by readers ( Idiagbon and Sani, 2008).

Pardo (2004) asserted that, the more background knowledge a reader has that connects with the text being read, the more likely the reader will be able to make sense of what is being read. She added, the process of connecting known information to new information takes place through a series of networkable connections known as schema. In schema theory, individuals organize their world knowledge into categories and systems that make retrieval easier. When a key word or concept is encountered, readers are able to access this information system, pulling the ideas that will help them make connections with the text. So, readers can create meaning and comprehend the text.

Landi (2010) stated that reading comprehension is a complex process that requires the coordination of bottom up word level skills 
and top down meaning processing skills. Much research over the past several decades has focused on the decoding component of this equation, demonstrating strong correlations between low-level decoding skills and reading comprehension. More recent research has examined the unique contribution of higher-level skills to reading comprehension.

El-Marsafy (2009) defined reading comprehension as the process of getting the whole meaning from the text clues based on the readers' background information. This process demands interaction between the reader and the text. This means that the readers construct meaning from the text, as they interact with the text by making predictions and organizing information. In so doing, the readers make a connection between what they already know and what they are reading to get a clear and coherent meaning of the new text.

Snow (2002) defined it as a process of extracting and constructing meaning through interaction and involvement with the written language.

The present study defines reading comprehension as a dynamic process in which the students interact with the texts according to the prior knowledge in order to construct and extract the writer's message.

Adaramaja (2008) indicated that reader can comprehend text in three different ways: By reading on the lines: simply look and lift factual information from the text (who, what, when, where and how).Summarize the main ideas in your own words. By reading between the lines- infer or figure out information provided by clues in the text and for by relating these to your background knowledge of the 
world. Work out the meaning of a word or phrase from clues in the text. Figure out an underlying theme, message or reason. Comment on the way language is used. By reading beyond the lines - apply ideas from the text to another situation. Evaluate ideas and formulate your own opinion. Apply ideas from the text to another situation.

Reading comprehension skills are classified into literal comprehension (on the line), interpretive or inferential (between the lines) comprehension and critical comprehension (beyond the lines). Literal comprehension involves surface meanings and teachers can ask students to find information and ideas that stated in the passage .At the second level (interpretive) students go beyond what is said and read for deeper meanings. It involves the ability to assess the accuracy or worth of materials read and includes thinking processes such as drawing conclusion, making generalization and predicting outcomes. The last level is critical reading where the ideas and information are evaluated. It involves the ability to apply meaning to one's own life (Wilcox ,1994), (Shehata ,2006), Lipka and Siegel (2011), Grant, Gottardo and Geva (2012) and Hudson, Torgesen, Lane and Turner (2012).

The previous studies clarified the traditional taxonomy of reading comprehension levels that contain different skills. As mentioned above, the traditional taxonomy consisted of three levels which are literal, inferential and critical levels. Then Al-Jarf (2007) and Billy (2008) proposed and added a new taxonomy that has a new level. They asserted that comprehension has four hierarchical levelsliteral, inferential, critical, and creative respectively. 
The literal level requires the reader to recall facts that are overtly stated in the text. Such facts could be names, things or ideas. This is the most elementary of the skills, and the learner would have acquired it appreciably by the end of primary schooling. The skill is not strong enough to enable the learner add any novel personal information.

The inferential skill empowers the reader to suggest relevant additional information based on the text confronted and personal experience. Such as; inferring supporting details, comparison, causeeffect relationships, figurative language and predicting outcomes.

The critical reading skill leads to the making of balanced judgments about the author's style and/or some other aspects of the text. It also refers to the judging the language and effect of the text in the light of appropriate criteria.

At the creative (which is the highest) level of reading, the reader is able to bring out something new, personal and relevant to the text. It could be by suggesting an alternative title, summarizing the text, or re-writing part or all of it.

Accordingly, reading comprehension is a complex process that needs the mastery of different skills at different levels. Learners must have a positive attitude towards reading that helps them to acquire and develop their reading comprehension skills. The English teacher should generate a conductive class environment to enhance language learning and to promote positive attitude in learning. Educators should also motivate students during the first meeting by encouraging them to learn English, frequently reminding them of the importance of mastering English; to attain their personal goals such as to further studies, travel 
abroad, prepare for the working world and be able to access the world of ICT (Bidin, Jusoff, Abdel Aziz, Salleh and Tajudin ,2009; and Kircher ,2014).

Student attitudes toward reading are a central factor affecting reading performance. Students that do not enjoy typical school texts often fail to engage in reading, and may develop a lifelong disrelish to reading. Even if they are not initially struggling readers, opposed readers tend to gradually lose some academic ground, because wide reading is related to increases in general knowledge and reading comprehension (Seitz , 2010).

Wenden (1991) cited in Karahan (2007) asserts that attitudes includes three components: First, attitudes tend to have a cognitive component. This could involve beliefs or perceptions about the objects or situations related to the attitude. Second, attitudes have an affective component. This means that the objects or situations related to attitude may generate like or dislike. Third, attitudes have a behavioral component, i.e. certain attitudes tend to promote learners to adopt particular learning behaviors. Accordingly, there are three component of attitude towards reading which are cognitive, behavioral and affective.

A positive attitude toward reading is essential for successful mastery of the printed pages. The teacher's job is to set goals and tasks at which most of his or her students can be successful. Much of the teacher's work in the classroom involves dealing with the challenges in a right way. 
It can be said that because of the importance of reading comprehension and attitude towards reading to the learners of English, some researchers have conducted many studies to develop EFL reading comprehension skills and attitudes towards reading.

The research made a study that investigating the effectiveness of using an electronic guided reading instruction (EGRI) program to develop EFL reading comprehension skills and attitudes towards reading among second year preparatory stage pupils. The researcher prepared a post reading comprehension test. The test consists of four texts and reading comprehension questions after every text. The first text measures the literal reading comprehension level. The second text measure the inferential comprehension level, The third text measures the evaluative comprehension level. And the fourth text measure the creative comprehension level. The total grade of the test is (70).

The researcher prepared an attitude towards reading scale which has three main components which are cognitive, behavioral and affective. Every component has ten items that measure it. The total grade of the scale is (90).

The researcher applied the post reading comprehension test and the attitude towards reading after administering the EGRI program to the experimental groups.

\section{Statement of the problem:}

The problem of the present research can be defined in the second year preparatory stage pupils' inefficient reading comprehension skills and their low attitude towards reading. Therefore, the present research is an attempt to investigate the relationship between EFL reading comprehension skills and attitude towards reading. 


\section{Question of the Research:}

- To face this problem, the present research is an attempt to answer the following question:

- What is the correlation relationship between the EFL reading comprehension skills and attitude towards reading?

\section{Hypothesis s of the Research:}

"There is a positive correlation relationship between EFL reading comprehension skills and attitude towards reading among second year preparatory stage pupils."

\section{Instruments of the Research:}

- A post reading comprehension test.

- A proficiency rating scale.

- An attitude towards reading scale.

\section{The validity of the reading comprehension tests:}

In order to validate the reading comprehension tests, they were submitted to jury members in Curricula and Methods of Teaching English. They were asked to indicate the suitability of tests' content for the academic level of the pupils and the clarity of instructions. They also indicated whether the passages were difficult and long or not; the suitability of the test and how far each question measure the skills intended to measure and whether the questions cover all the skills in the study. In the light of the jury's suggestions and notes which took into consideration, the modifications were performed and the content of the tests were modified in the final form. 


\section{Reliability of the reading comprehension tests:}

The test-retest methods was used to determine the reliability of the reading comprehension tests. As the researcher applied the tests to the sample and re- applied them after two weeks. The reliability correlation of the pre test $(0.83)$ and $(0.96)$ for the post test. So, it can be noticed that there are high significant positive correlation between the sample scores on both the pre and the post tests. So the reading comprehension tests are reliable.

\section{Validity of the scale:}

For assessing the validity of the scale, it was submitted to a jury of professors who suggested the rewording of some words and retranslation of some items. The suggested changes were made

\section{Reliability of the Attitude towards reading scale:}

The re-application methods was used to determine the reliability of the attitude towards reading scale. As the researcher applied the scale to the sample and re- applied it after two weeks. The reliability correlation was (0.88) So, it can be noticed that there is a high significant positive correlation between the sample scores on attitude towards reading scale. So the attitude towards reading scale is reliable.

\section{The participants of the study:}

The participants of the present study was forty pupils in second year from Al-Shaheed Ahmed Hamid Abdel Dayem - a preparatory school at Al-Menofia Governorate- during the first semester of the academic year 2018-2019. The participants of the study were divided into three groups, two experimental groups (group one was consisted of ten pupils and the second group was also consisted of ten pupils and the control group was consisted of twenty pupils. 


\section{Findings of the Research:}

The findings of the present research are presented in the light of the hypothesis of the research using the Statistical Package for Social Science (SPSS) program version 23.

The results were as follows:

\begin{tabular}{|c|c|c|c|}
\hline $\mathrm{N}$ & Variables & Correlation coefficient & Sig. \\
\hline 20 & $\begin{array}{c}\text { EFL reading } \\
\text { comprehension } \\
\text { skills } \\
\text { Attitude towards } \\
\text { reading }\end{array}$ & 0.604 & 0.01 \\
\hline
\end{tabular}

The previous table indicates that the correlation coefficient between the EFL reading comprehension skills and attitude towards reading is (0.604) which is significant at the (0.01) level of significance. This means that the development in EFL reading comprehension skills is followed by increasing in attitude towards reading.

\section{Conclusion:}

Based on teaching reading comprehension skills by using EGRI program which involves different texts (fiction, non-fiction and biographical) and different strategies for improving EFL reading comprehension skills. These texts and strategies are varied in every session according to the skills which ere in scope during the session, the EFL reading comprehension skills were developed and the attitudes towards reading also developed and there is a positive correlation relationship between the EFL reading comprehension skills and attitudes towards reading. Accordingly, when the EFL reading comprehension skills become high, the attitude towards reading becomes high. 


\section{References}

- Abdel-Haq, E. (2009) Using reciprocal teaching to improve strategic reading and reading comprehension skills of EFL majors El-Marasafy, A. and Abdel-Hack, E.(eds); : New Trends in Teaching Reading and Writing. Egypt: Middle East Center

- Adaramaja, S. (2008) Strategies for reading . Shehu, R., Ahmed, A. and Abdulrasaq, M. In (eds.) How to promote reading skills among JSS students for English language teachers. Integrity Publications, Ilorin. Pp.33-50

- Al-Jarf, R. (2007) Developing reading and literacy in Saudi Arabia, King Saud University, Riyadh, Saudi Arabia.

- Bidin, S., Jusoff, J., Abdel Aziz, N., Salleh, M. and Tajudin, T. (2009) Motivation and attitude in learning English among UITM students in the northern region of Malaysia, English Language Teaching, 2, 2 pp 16-20

- Billy, O. (2008) Teaching basic reading comprehension skills at junior secondary school level. Shehu, R., Ahmed, A. and Abdulrasaq, M. . In (eds.) How to promote reading skills among JSS students for English language teachers. Integrity Publications, IIorin. Pp. 1- 12

- El-Marsafy, A. (2009) Utilizing SQ3R system to enhance special diploma students' reading. In A. El-Marsafy, and E. Abdel-Haq, (eds), New Trends in Teaching Reading \& Writing from Theory to Practice, (pp.271-332), Benha - Egypt: Middle East Centre for Educational Services. 
- Fountas, I. and Pinnell, G. (2001) Guided readers and writers (grades 3-6): Teaching comprehension, genre, and content literacy. Portsmouth, New Hampshire: Heinemann.

- Gentaz, E., Charolles, L. and Theurel, A. (2015) Differences in the predictors of reading comprehension in first graders from low socio-economic status families with either good or poor decoding skills, PLOS ONE | DOI:10.1371/journal.pone.0119581 ,10, 3 pp $1-16$

- Grant, A. Gottardo, A. and Geva, E. (2012) Measures of reading comprehension: Do they measure different skills for children learning English as a second language? Read Writ 25,1899 1928, Published online: 30 March 2012, Springer Science + Business Media B.V. 2

- Hashey, J and Conners, D. (2003) Learn from our Journey: Reciprocal Teaching Action Research. The Reading Teacher.57, pp.224-232.( Available at; www.ebscohost. Com)

- Harmer, J. (2007) The Practice of English Language Teaching, Pearson, Longman, Fourth Edition

- Hudson, R., Torgesen, J., Lane, H. and Turner, S. (2012) Relations among reading skills and sub-skills and text-level reading proficiency in developing readers, Read Writ , 25:483507, Springer Science+Business Media B.V. 2010

- Ibrahim,S. (2007) Training program in learning meta cognitive strategies in English to improve reading comprehension for lowachievers in preparatory school. Unpublished M.A Thesis, Faculty of Education. Ain shams University. 
- Idiagbob, A. \& Sani, M. (2008) Identifying reading comprehension skills. Shehu, R., Ahmed, A. and Abdulrasaq, M, In (eds.) How to promote reading skills among JSS students for English language teachers. Pp. 13-22 Integrity Publications, IIorin.

- Joseph, L. (2004) Reading encouraging positive attitudes: strategies for parents and teachers. National Association of School Psychologists, 301???????

- Karahan, F. (2007) Language attitudes of Turkish towards the English language and it's use in Turkish context, Journal of Arts and Science, 7 pp 73-87

- Kewaza, S. \& Welch, M.( 2013) Big class size challenges: teaching reading in primary classes in Kampala, Uganda's Central Municipality. US-China Education Review 3( 5), 283296

- Kircher, R. (2014) Thirty years after bill 101: A contemporary perspective on attitudes towards English and French in Montreal, The Canadian Journal of Applied Linguistics: 17, 1 pp. 20-50

- Landi, N. (2010) An examination of the relationship between reading comprehension, higher-level and lower-level reading sub-skills in adults, Read Writ 32, 701-717.

- Lipka, O. \& Siegel, L. (2012) The development of reading comprehension skills in children learning English as a second language. Read Writ 25 pp. 1873-1898 
- Macaruso, P. \& Shankweiler, D. (2010) Expanding the simple view of reading in accounting for reading skills in community college students, Reading Psychology, 31,454-471

- Mohamed, F. Abdel-Haq, E. \&Helwa, H (2010) Using K.W.L. plus strategy for developing some reading skills among EFL freshmen. Journal of Benha Faculty of Education, 82 ,(2 ),1-32.

- Nation, K. , Cocksey, J. Taylor, J. \& Bishop, D. (2010). A longitudinal investigation of early reading and language skills in children with poor reading comprehension .Journal of Child Psychology and Psychiatry,51(9) , 1031-1039

- Pardo, L. (2004) What every teacher needs to know about comprehension, International Reading Association,58,(3) pp. $272-280$

- Rahman, H. (2007) An evaluation of the teaching of reading skills of English Bangladesh (Unpublished doctoral Dissertation). University of Rajshahi, Bangladesh.

- Roch,M., Florit, E. \& Levorato, C. (2011) Follow-up study on reading comprehension in Down's syndrome: the role of reading skills and listening comprehension, International Journal of Language \& Communication Disorders 46,( 2) 231-242, Department of Developmental Psychology, University of Padua, Padua, Italy

- Rraku, V.( 2013) The effect of reading strategies on the improvement of the reading skills of students. University of Tirana, Branch of Saranda, Albania, Social and natural sciences journal 7,(2) pp 1-30. 
- Seitz, L. (2010) Student attitude toward reading: A case study, Journal of Inquiry and Action in Education, 3 (2), pp.30-44

- Shehata, M. (2006) The effectiveness of semantic mapping strategy and DRTA strategy in developing Benha High Institute of Technology Students reading comprehension skills, Unpublished M.A thesis faculty of Education, Benha university

- Snow, C. (2002) Reading for understanding : Towards a research and development program in reading comprehension. Santa Monica: Brand Education.

- Sobra, B. (1995) Lifelong Readers, The Educational Resources of Information Centre (ERIC), School of education, Dominican college

- Wilcox,B.(1994) The effects of marginal gloss study guides on expository reading comprehension of the fifth-grade students. UnPublished Ph.D Thesis, University of Wyoming. 